DOI: https://doi.org/10.32838/2523-4803/71-3-4

удК 330.8

\title{
Самойленко А.О.
}

кандидат економічних наук,

доцент кафедри туристичного бізнесу та гостинності,

Дніпровський національний університет імені Олеся Гончара

Хрулькова К.А.

студентка,

Дніпровський національний університет імені Олеся Гончара

Samoilenko Alla, Khrulkova Kateryna

Oles Honchar Dnipro National University

\section{КРЕАТИВНІСТЬ ЛЮДСЬКОГО КАПІТАЛУ В ГОТЕЛЬНІЙ ІНДУСТРІЇ}

\begin{abstract}
У статті розглянуто сутність людського капіталу з позииії його креативності в готельній індустрії. Представлено групи творчих активів, щзо формують креативність людського капіталу. Досліджено Стратегію сталого розвитку України до 2030 р., зокрема у напрямі «Креативні індустрії та індустрія гостинності», на базі якої виявлено стратегічні заходи створення конкурентоспроможної креативної економіки. Представлено методи мотивачї̈ персоналу на підприємствах готельного бізнесу та особливості системи мотивації на підставі факторних чинників. Охарактеризовано компоненти нематеріального стимулювання у готельному бізнесі щзодо підвищення креативності людського капіталу. Виявлено, що мотивація людського капіталу в готельній індустрії є важливим чинником успішної діяльності підприємств иієї сфери, а також значимим засобом підвищення креативності людського ресурсу. Також наголошено, щзо методи мотивації мають грунтуватися на індивідуальному підході.
\end{abstract}

Ключові слова: креативний людський капітал, готельна індустрія, мотивачія персоналу, людський актив, стимулювання праці.

Постановка проблеми. У будь-якій галузі, до якої також входить індустрія гостинності, креативність людського капіталу, мотивація роботи та рівень задоволення персоналу готельного підприємства відіграють важливу роль у визначенні успіху чи невдачі організації. Це передусім пояснюється тим, що сьогодні для будь-якої компанії людський капітал та персонал розглядаються як важливий актив, який суттєво сприяє виживанню та зростанню цієї компанії. Оскільки кожен актив бізнесу вимагає належної уваги, інвестицій та управління з боку власників, це також стосується і людського капіталу, який у готельній індустрії відіграє ключову роль. Саме тому його креативність впливатиме на позиціонування готельної індустрії на світовому ринку туристичних послуг, що є важливим завданням наукового пошуку в контексті побудови важливих компонент і засобів його підвищення та розвитку.

Аналіз останніх досліджень і публікацій. Питанням вивчення креативності людського капіталу присвячено роботи Л.Л. Калініченко, Т.В. Поснової, К.С. Шапошникова. Значний внесок у методологію дослідження мотивації людського капіталу зробили такі іноземні та вітчизняні науковці, як Дж. Белл, Дж. Гелбрейт, В. Геєць, А. Гальчинський, П. Друкер, Ф. Махлуп, Ф. Фукуяма, С. Крамер, Л. Лейдесдорф, П. Ромер, В. Остапенко, Л. Федулова, С. Сардак, В. Семиноженко, Э. Тоффлер, Ч. Пауерс, Дж. Хейдж та ін. Разом із тим дослідження креативності людського капіталу в готельній індустрії потребує більш детальної уваги сучасних науковців та подальшого висвітлення.

Формулювання цілей статті. Метою статті $\epsilon$ дослідження сутності креативного людського капіталу та його ролі в готельній індустрії.

Виклад основного матеріалу. У сучасному світі все частіше звертають увагу на людський капітал та його роль у впливі на продуктивність економіки та роботу організації. При цьому знання перетворилися на основний чинник виробництва, який відрізняється своїми властивостями від інших факторів, вони не витрачаються, не зменшуються і не зникають у процесі виробництва. Особливого значення набуває те, що людський капітал стає джерелом саморозвитку та вдосконалення людини, характеризуючи якісне зростання економіки знань. У таких умовах креативна діяльність людини, іiі прагнення реалізувати себе та свої здібності поступово виходять на перший план [1].

Креативність людського капіталу виявляється у сукупності творчих якостей людини, які виступають ii «активами» та поділяються на такі основні групи залежно від їхніх функцій у життєдіяльності:

- жива система людини, яку становлять загальні фізичні та нервово-психічні, у тому числі інтелектуальні, можливості людини, зокрема потенціал його здоров'я; 
- здатність до індивідуального відтворення самого себе в широкому значенні через підтримання, збереження та примноження свої власних можливостей, у тому числі й продовження роду. У це поняття входять специфічні знання та вміння, необхідні людині для формування та вдосконалення власних творчих здібностей;

- рівень освіти та професійний рівень, у тому числі загальноосвітні та соціокультурні знання та вміння, загальні та спеціальні професійні навички, трудовий досвід та виробнича майстерність;

- когнітивні можливості, необхідні для успішного отримання, переробки, зберігання та використання економічно значущої інформації, інформативність у виробничій діяльності людини;

- мобільність та свобода переміщення;

- свобода доступу до системи освіти;

- готовність та можливість зміни соціального статусу індивіда;

- система стимулів та мотивів як комплекс факторів соціально-економічного характеру, що пов'язані із системою цінностей і мотивацій людини до праці, та їі найважливіші особистісні якості [1].

Мотивація є важливим засобом забезпечення креативного розвитку людського капіталу та оптимального досягнення успіху організації. К.С. Шапошников обгрунтував роль інституційного середовища у креативному розвитку економіки. Він відзначив, що інституційне середовище має забезпечувати постійний пошук і реалізацію нових можливостей в економічному розвитку, взаємодію всіх учасників цього процесу, стимулювання і підтримку обміну ідеями між ними, сприяти створенню конкурентоспроможності економіки та реалізації інтересів спільноти [3].

Важливість та необхідність впливу креативного складника людського капіталу на розвиток національної економіки відображено також у Стратегії сталого розвитку України до 2030 р. [4]. Важливою стратегічною метою є забезпечення сталого галузевого та регіонального розвитку через механізм збереження національних культурних цінностей і традицій регіонів. Відповідно до Стратегії, у напрямі «Креативні індустрії та індустрія гостинності» стратегічною метою $є$ створення конкурентоспроможної креативної економіки, забезпечення розвитку туризму як одного з драйверів соціокультурного та економічного розвитку регіонів. Відповідно важливими стратегічними заходами $є$ :

- збільшення частки креативних індустрій у доданій вартості з 3,86\% до 5\%;

- збільшення частки креативних товарів в експорті від $0,5 \%$ до $3 \%$;

- збільшення кількості зайнятих із 3,57\% до 4,5\% від загальної кількості працевлаштованих;

- підвищення позиції у Глобальному індексі інновацій у категорії Creative goods and services з 95-ї на 25-ту;

- підвищення захищеності прав інтелектуальної власності;

- посісти 45-е місце у The Travel \& Tourism Competitiveness Index;
- поліпшення доступу представників креативних індустрій до фінансових ресурсів;

- забезпечення високої якості сервісу та безпеки у сфері туризму [4].

Мотивація людського капіталу в готельній індустрії $\epsilon$ важливим чинником успішної діяльності підприємств цієї сфери, а також значимим засобом підвищення креативності людського ресурсу. Методи мотивації мають грунтуватися на індивідуальному підході. Необхідно визначити ключові потреби певної групи працівників i розробляти відповідні мотиваційні заходи для них. Для одних працівників пріоритетне значення мають фізіологічні потреби, для інших - потреби визнання i самоствердження [5].

Важливим мотиваційним засобом підвищення креативності для більшості працівників підприємства є заробітна плата. Матеріальна мотивація у трудовій діяльності розглядається з позиції комплексної дії низки макро- й мікроекономічних чинників, у тому числі [6]:

а) рівня заробітної плати та їі динаміки;

б) наявності прямої залежності рівня заробітної плати від кількості, якості й результатів праці;

в) диференціації заробітної плати на підприємстві та в суспільстві загалом;

г) структури особистого доходу;

г) матеріального забезпечення наявних грошових доходів тощо.

Сучасне готельне підприємство повинне виставляти конкурентну заробітну плату для того, щоб стимулювати своїх співробітників до якісної роботи. Проте досить відомим фактом є те, що людина швидко звикає до нового і заробітна плата не є винятком, тому в готельній індустрії, окрім економічних методів мотивації, мають бути застосовані соціальні, статусні, морально-психологічні та низка інших методів, що представлені на рис. 1.

Керівники підприємств, вибираючи тій чи інший метод мотивації, керуються принципом доцільності та можливості підвищення креативності людського капіталу, які спрямовані на задоволення потреб безпеки та захищеності, належності та причетності, поваги та самоствердження. До таких методів належать гарантія стабільної зайнятості, створення сприятливого соціально-психологічного клімату, атмосфери взаємодопомоги, розвиток командної роботи, повага та визнання результатів роботи кожного члена команди, залучення до процесів прийняття рішень, спільного обговорення стратегії розвитку підприємства, організація навчання тощо.

Система соціальних заохочень і винагород також відіграє особливу роль у мотиваційному механізмі готельної індустрії, яка складається з медичного страхування працівників, допомоги співробітникам, забезпечення відпочинку дітей, позики на придбання житла, організації безкоштовних обідів тощо [8].

У готельній індустрії на креативність людського капіталу також впливають особливості системи мотивації, що залежать від таких чинників [7]: 


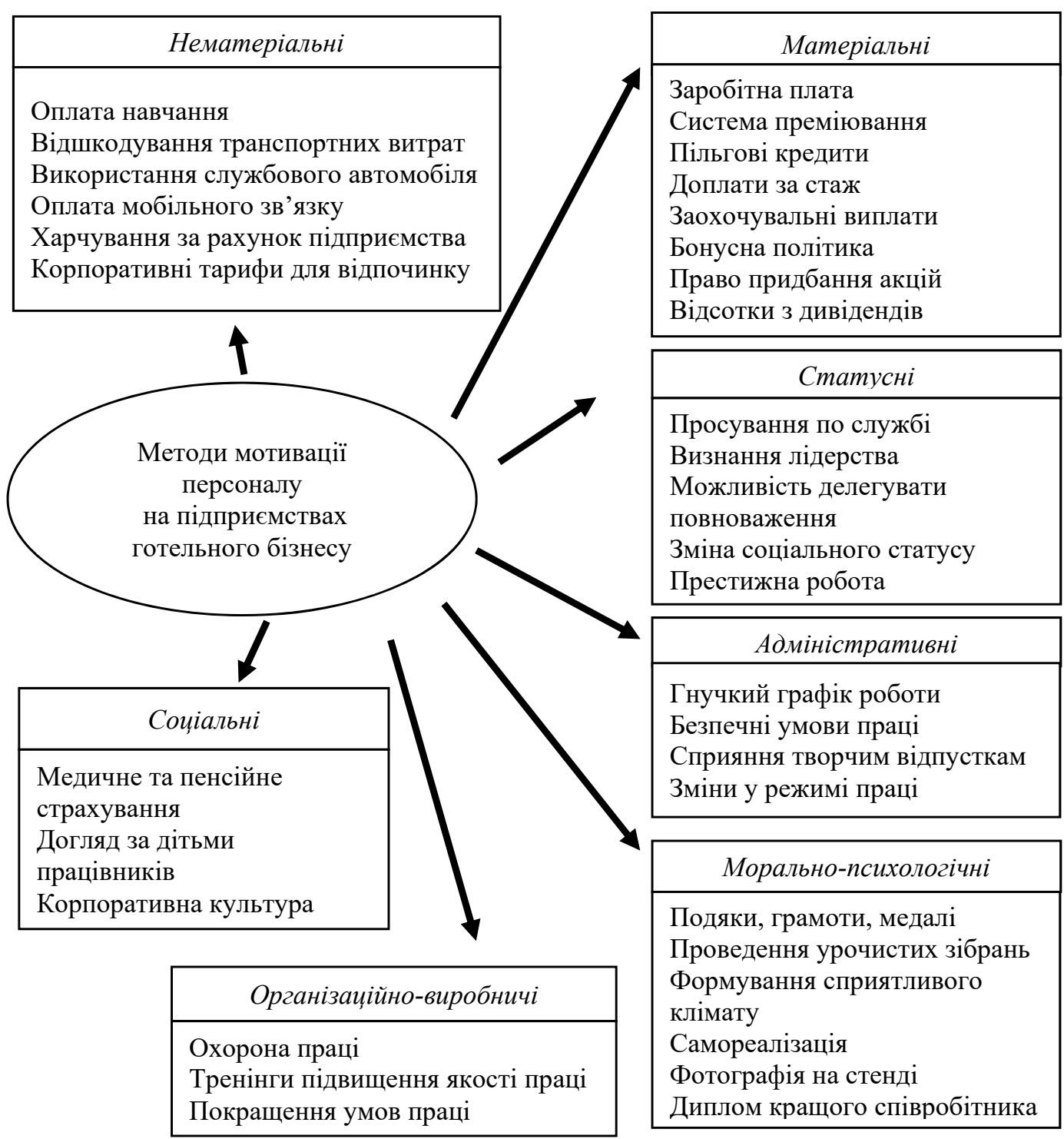

Рис. 1. Методи мотивації персоналу на підприємствах готельного бізнесу

Джерело: складено за даними [7-9]

- якщо готель відноситься до мережі (розробляються єдині програми);

- кон'юнктури ринку праці;

- враховуються особливості діяльності деяких співробітників (топ-менеджмент, запрошені 3 іншої країни співробітники).

При цьому до методів нематеріального стимулювання в готельному бізнесі відносяться [10]:

- наявність програми «співробітник місяця/кварталу/року». Такий метод хоча і носить змагальний характер, але він допомагає вести до збільшення трудових показників, за рахунок чого зростає і креативність людського капіталу. Право вибору найкращого працівника залишається за колективом;

- проведення корпоративних заходів. Такі заходи не тільки згуртовують колектив, а й дають змогу співробітнику проявити себе як особистість. Для співробітників індустрії гостинності, особливо для тих, хто знаходиться у постійній взаємодії з гостями, важливо мати можливість проявляти себе творчо, щоб передавати гостям тільки позитивні емоції;

- спілкування. Зв'язок «керівник - підлеглий» дуже важливий і може виявитися цінним для готельного бізнесу. Спілкування генерального директора, топ-менеджера зі своїми підлеглими допомагає налагодити необхідний рівень довіри і відкритися. Співробітник усвідомлюватиме, що він не байдужий для керівництва й $є$ важливою частиною колективу. Прикладом цього можуть послужити ті ж корпоративні «планерки» на початку дня, де керівник може «зарядити» позитивними емоціями і надавати настрій на весь трудовий день. Це підвищує емоційний настрій працівників на більш ефективне виконання своєї роботи;

- причетність - одна $з$ потреб людини, яка розташована на третьому рівні піраміди А. Маслоу. Організація зборів, у беруть участь співробітники керівних посад 
і лінійного персоналу, залучає підлеглих ближче до керівництва і до вирішення життєво важливих питань. Відчуття значущості і визнання в готельній індустрії особливо гостро спостерігається у лінійного персоналу;

- навчання і кар'єрне зростання. Коли людина, яка прагне до саморозвитку і професійного зростання, перестає отримувати нові знання і досвід, то вона починає шукати місце, де їй можуть це надати. У зв'язку із цим на успішних підприємствах прийнято проводити тренінги як у професійній сфері, так і загальноосвітні, курси іноземної мови, курси підвищення кваліфікації персоналу тощо;

- система бонусів і корпоративних знижок особливо популярна в готельному бізнесі. Знижки надаються співробітникам, а іноді й родичам співробітників на користування послугами готелю та його партнерів. Такими можуть бути салони краси при готелі, постачальники, фітнес-клуби, послуги професійного готельного фотографа тощо. Надаючи співробітникам корпоративні знижки, можна істотно підвищити якість послуг і сервісу.

Отже, завдяки нематеріальним способам мотивації буде можливим підвищення рівня креативності людського капіталу в готельній індустрії, оскільки працівники також не матимуть бажання змінювати місце роботи і будуть із великим ентузіазмом та енергією віддаватися роботі.

Окрім нематеріальних методів мотивації, організація розробляє матеріальну систему мотивації співробітників. У готельному бізнесі широко використовують метод мотивації співробітників по відділах, тобто розробляють програми для окремих відділів із метою збільшення прагнення персоналу виконувати свою роботу краще й якісніше.
Працівники готельної індустрії, окрім оригінальних знань, креативних здібностей та наявності вроджених талантів, повинні володіти також такими компетенціями, як:

- спроможність генерувати нові ідеї та рішення;

- схильність критично ставитися до власних ідей та ідей інших людей;

- спроможність ідентифікувати нові можливості;

- спроможність публічно презентувати свої ідеї та напрацювання;

- спроможність координувати свою діяльність;

- спроможність набувати нові знання;

- аналітичне мислення;

- спроможність ефективно використовувати власний час;

- спроможність вести перемовини;

- спроможність говорити та писати іноземними мовами тощо [1].

Висновки. Отже, в умовах трансформації економічних процесів креативність людського капіталу стає важливим потенціалом суб'єкта у будь-якій індустрії. Тому необхідність масштабних інновацій, створення ефективної системи мотивацій, відповідного рівня освітньої та наукової системи в країні стануть першочерговими заходами на шляху підвищення продуктивності людського капіталу в індустріальній сфері економіки. Креативний людський капітал здатний помітно посилювати свої конкурентні позиції на ринку праці. У такому напрямі більш освічені працівники зможуть успішніше адаптуватися до змін в економічному і соціальному середовищі, активніше освоювати нові знання i навички, швидше реагувати на досягнення науковотехнічного прогресу та починати раніше впроваджувати їх у своїй повсякденній діяльності.

\section{Список літератури:}

1. Поснова Т.В. Роль креативного людського капіталу в економіці знань. Modern Economics. 2019. № 14. С. $232-236$. URL: https://modecon.mnau.edu.ua/issue/14-2019/posnova.pdf (дата звернення: 25.05.2021).

2. Поснова Т.В. Оцінка впливу креативного людського капіталу на економічний розвиток регіонів України. Держава та регіони. Серія «Економіка та підприємництво». 2021. № 1(118). C. 29-36. URL: http://www.econom.stateandregions.zp.ua/journal/2021/1_2021/7.pdf (дата звернення: 25.05.2021).

3. Шапошников К.С. Вплив інституційного середовища на креативний розвиток економіки регіону. Наукові праці Кіровоградського начіонального технічного університету. Економічні науки. 2013. Вип. 23. C. 206-210. URL: http://nbuv.gov.ua/UJRN/Npkntu_e_2013_23_31 (дата звернення: 25.05.2021).

4. Національна економічна стратегія - 2030. URL: https://nes2030.org.ua/docs/doc-vector.pdf (дата звернення: 25.05.2021).

5. Колот А.М. Мотивація персоналу : підручник. Київ : КНЕУ, 2011. 397 с.

6. Калініченко Л.Л. Мотивація персоналу як чинник підвищення якості послуг підприємств готельного бізнесу. Глобальні та національні проблеми економіки. 2014. Вип. 2. С. 948-951. URL: http://global-national.in.ua/ archive/2-2014/196.pdf (дата звернення: 25.05.2021).

7. Попик М.М. Формування механізму мотивації персоналу готельно-ресторанного бізнесу на основі концепції маржинального прибутку. Східна Європа: економіка, бізнес, управління. 2019. Вип. 4(21). С. 311-318.

8. Устіловська А.С. Мотивація персоналу як один з основних інструментів успішного управління персоналом. Молодий вчений. 2017. № 4.4. С. 112-115.

9. Сардак С.Е. Мотивація та стимулювання працівників вітчизняних підприємств. Україна: аспекти праці. 2008. № 6. С. 45-51.

10. Моргулець О.Б. Менеджмент у сфері послуг : навчальний посібник. Київ : Центр учбової літератури, 2012. 384 c. 


\section{References:}

1. Posnova T.V. (2019) Rol kreatyvnoho lyudskoho kapitalu v ekonomitsi znan [The role of creative human capital in the knowledge economy]. Modern Economics, no. 14, pp. 232-236. Available at: https://modecon.mnau.edu.ua/issue/14-2019/ posnova.pdf (accessed 25 May 2021).

2. Posnova T.V. (2021) Otsinka vplyvu kreatyvnoho lyuds'koho kapitalu na ekonomichnyy rozvytok rehioniv Ukrayiny. [Assessment of the impact of creative human capital on the economic development of the regions of Ukraine]. Derzhava ta rehiony. Seriya: Ekonomika ta pidpryyemnytstvo, no. 1 (118), pp. 29-36. Available at: http://www.econom.stateandregions.zp.ua/ journal/2021/1_2021/7.pdf (accessed 25 May 2021).

3. Shaposhnykov K.S. (2013) Vplyv instytutsiynoho seredovyshcha na kreatyvnyy rozvytok ekonomiky rehionu [The influence of the institutional environment on the creative development of the region's economy]. Scientific works of Kirovograd National Technical University. Economic sciences, vol. 23, pp. 206-210 (accessed 25 May 2021).

4. Cabinet of Ministers of Ukraine (2020). Natsionalna ekonomichna stratehiya 2030 [National Economic Strategy 2030]. Available at: https://nes2030.org.ua/docs/doc-vector.pdf (accessed 25 May 2021).

5. Kolot A.M. (2011) Motyvatsiya personalu: pidruchnyk [Staff motivation: a textbook]. Kyiv: KNEU. 397 p.

6. Kalinichenko L.L. (2014) Motyvatsiya personalu yak chynnyk pidvyshchennya yakosti posluh pidpryyemstv hotelnoho biznesu. [Motivation of staff as a factor in improving the quality of services of hotel business enterprises]. Hlobalni ta natsionalni problemy ekonomiky, no. 2, pp. 948-951. Available at: http://global-national.in.ua/archive/2-2014/196.pdf (accessed 25 May 2021).

7. Popyk M.M. (2019) Formuvannya mekhanizmu motyvatsiyi personalu hotel'no-restorannoho biznesu na osnovi kontseptsiyi marzhynal'noho prybutku. [Formation of the mechanism of motivation of the personnel of hotel and restaurant business on the basis of the concept of marginal profit]. Skhidna Yevropa: ekonomika, biznes, upravlinnya, no. 4 (21). pp. 311-318.

8. Ustilovska A.S. (2017) Motyvatsiya personalu yak odyn z osnovnykh instrumentiv uspishnoho upravlinnya personalom [Staff motivation as one of the main tools for successful personnel management]. Molodyy vchenyy, no. 4.4. pp. 112-115.

9. Sardak S.E. (2008) Motyvatsiya ta stymulyuvannya pratsivnykiv vitchyznyanykh pidpryyemstv [Motivation and stimulation of employees of domestic enterprises]. Ukrayina: aspekty pratsi [Ukraine: aspects of work], no. 6. pp. 45-51.

10. Morhulets O.B. (2012) Menedzhment u sferi posluh. Navch. posib. [Management in the field of services. Teaching. Way]. Kyiv: Tsentr uchbovoi literatury, 384 p.

\section{КРЕАТИВНОСТЬ ЧЕЛОВЕЧЕСКОГО КАПИТАЛА В ГОСТИНИЧНОЙ ИНДУСТРИИ}

В статье рассмотрена сущность человеческого капитала с позиции его креативности в гостиничной индустрии. Представлены группь творческих активов, формирующих креативность человеческого капитала. Исследована Стратегия устойчивого развития Украины до 2030 г., в частности в направлении «Креативные индустрии и индустрия гостеприимства», на базе которой выявлены стратегические меры по созданию конкурентоспособной креативной экономики. Представлены методы мотивации персонала на предприятиях гостиничного бизнеса и особенности системы мотивации на основе групп факторов. Охарактеризованы компоненты нематериального стимулирования в гостиничном бизнесе по повышению креативности человеческого капитала. Выявлено, что мотивачия человеческого капитала в гостиничной индустрии является важным фактором успешной деятельности предприятий этой сферы, а также значимым средством повышения креативности человеческого ресурса. Также отмечено, что методы мотивации должны основываться на индивидуальном подходе.

Ключевые слова: креативный человеческий капитал, гостиничная индустрия, мотивация персонала, человеческий актив, стимулирование труда.

\section{CREATIVITY OF HUMAN CAPITAL IN THE HOTEL INDUSTRY}

The article considers the essence of human capital from the standpoint of its creativity in the hotel industry. Groups of creative assets that form the creativity of human capital are presented. The Strategy of Sustainable Development of Ukraine until 2030 is studied, in particular in the direction of "Creative Industries and Hospitality Industry", and on the basis of which strategic measures to create a competitive creative economy are identified. It is noted that material motivation in labor activity is considered from the standpoint of the complex action of a number of macro- and microeconomic factors, including: the level of wages and its dynamics; the presence of a direct dependence of the level wages from quantity, quality and results of work; wage differentiation in the enterprise and in society as a whole; personal income structure; material support of available cash income, etc. Methods of personnel motivation at hotel business enterprises and features of motivation system on the basis of factor factors are presented. The components of intangible incentives in the hotel business to increase the creativity of human capital are described. It was found that the motivation of human capital in the hotel industry is an important factor in the successful operation of enterprises in this area, as well as a significant means of increasing the creativity of human resources. It is also emphasized that motivation methods should 
be based on an individual approach. The creative abilities and competencies that a modern employee of the hotel industry should have are proposed, namely: the ability to generate new ideas and solutions; tendency to be critical of one's own ideas and the ideas of others; the ability to identify new opportunities, publicly present their ideas and experiences, coordinate their activities and acquire new knowledge. Intangible ways of motivation will make it possible to increase the level of creativity of human capital in the hotel industry, as employees will also not be willing to change jobs and will be very enthusiastic and energetic to work. In the hotel business, the method of motivating employees by departments is widely used. Programs are being developed for individual departments in order to increase the desire of staff to perform their work better and better.

Key words: creative human capital, hotel industry, staff motivation, human assets, labor stimulation. 